\title{
Introduction
}

\section{Children at Risk}

\author{
Geraldine Sadoway
}

C hildren are at risk in every part of the world today. They are at risk because of their special vulnerability as children and because the "natural" urge of most adults to protect and care for children falls far short of ensuring their protection and care. Children are particularly at risk when they are separated from their parents and families due to war, poverty, and oppression, or when their caregivers have themselves become their exploiters and persecutors. According to UNICEF's most recent State of the World's Children report, an estimated twenty-seven thousand children under five died of preventable causes per day in 2001. Jo Becker, Director of Human Rights Watch, states that "children are at risk of violence in nearly every aspect of their lives-in their schools, on the street, at work, in institutions, and in areas of armed conflict. They are beaten, tortured, sexually assaulted, and murdered, often by the very individuals responsible for their care and safety."

The community and the state have often been reluctant to intervene to protect children. Paternalistic concepts of children as property-chattels of their parents, or extensions of their parents-rather than as persons in their own right are deeply ingrained. The recognized need to protect the private sphere of personal and family relations from undue state interference is another barrier. But gradually we have come to recognize basic human rights of all children and to enshrine these rights in international treaties and conventions, such as the United Nations Convention on the Rights of the Child (CRC), the most widely ratified of international human rights conventions. ${ }^{2}$

Almost all children have some ability to express their needs, from the infant crying to express hunger or cold, to the nineyear-old refugee from Sierra Leone who approaches a Guinean woman and asks her to take him with her because he has no one else to care for him, or the teenage refugee in Canada who recognizes the injustice and humiliation of being a "brownpaper" person because of her lack of immigration status. But having a voice is one thing, having the power to escape from oppression and persecution is another. Children lack power in our society and are therefore dependent upon adults to recognize their needs and act to ensure their care and development, as well as their safety and protection.

In this issue of Refuge we have an opportunity to examine what is happening in different parts of the world to the most vulnerable members of the world community. The essay "Hidden Children" by Moller and Minard describes the situation of separated refugee children from Sierra Leone who are being fostered by families in neighbouring Guinea. This can be compared, ironically, to the predicament of children who have reached the "golden mountain" of the United States, only to find themselves imprisoned in the "care" of the INS while their status is adjudicated. It is not surprising to discover that the attention lavished on little Elián Gonzalez, the shipwrecked six-year-old from Cuba, is far from typical. As Morton and Young point out in their piece, in the year 2000, while the battle for Elián raged in the media, "the INS took nearly five thousand children into its custody, some as young as eighteen months old."

Closer to home, Denov and Campbell reveal the ravages of internal displacement on a community and the grievous toll taken on its children. In their searing account of the Innu people of Davis Inlet, we learn that the Innu, who have twice been relocated by the Canadian government, are the "most suicide-ridden people in the world" and that "an Innu child is between three and seven times more likely to die before the age of five than the average Canadian child." Internal displacement occurs worldwide. In the report by Mahalingam, Narayan, and van der Velde, we gain insight into effective strategies developed by UNICEF for working with IDP children in a range of different countries, from Sri Lanka to Colombia, strategies that include empowering adolescent youth in refugee camps to becoming involved in 
resolving the challenges facing their own refugee population.

The issue of what constitutes "persecution" of children, in terms of the UN Convention for the determination of refugee status, continues to challenge adjudicators. The plight of children facing forced conscription, sexual exploitation, and female genital mutilation is beginning to gain recognition as persecution of children. Yet the more commonplace forms of ill-treatment, such as domestic servitude in private homes, may not be as readily recognized as such. The heartbreaking account by Irdèle Lubin of Haitian children given up by poor families to become domestic servants, in return for their room and board and the promise of education, and who become little slaves, mistreated, humiliated, and worked to death, is a harsh reminder of the utter vulnerability of such children and the need for effective state protection. In a summary of Indian jurisprudence by Veerabhadran Vijayakumar, we are given a glimpse of the role of the courts in defending the rights of refugee children and of curbing certain forms of persecutory treatment of children such as bonded or dangerous labour, slavery, trafficking, prostitution, and pornography.

In Canada, treatment of separated refugee children still leaves much to be desired, but the UNHCR, International Social Service (ISS), and the Child Welfare League have brought this issue to the forefront with a National Roundtable on Separated Refugee Children in October of 2001. Judith Kumin and Danya Chaikel review this important meeting in "Taking the Agenda Forward." They set out recommendations for action by federal immigration authorities and provincial child welfare providers if Canada's obligations under the UN Convention on the Rights of the Child are to be met. Catherine Montgomery's piece on the experience of unaccompanied refugee children in Quebec, "The 'Brown Paper Syndrome'," captures the voices of refugee youth, frustrated and confused by the refugee determination system in Canada and by the haphazard array of social services they must navigate successfully in order to survive. This research is a poignant reminder of the need to involve children themselves in the solution, underlining article 12 of the CRC, the right of the child "to express his or her own views freely in all matters affecting the child" and the assurance that the views of the child will be "given due weight in accordance with the age and maturity of the child." Sarah Crowe's article deals with protecting the rights of refused refugee children, again emphasizing the value of participation by the children themselves in the plan for their return to the country of origin, when return is the appropriate or unavoidable outcome. She also describes the important role of NGOs such as International Social Service in negotiating a long-term solution for the children affected.

This collection gives us a sense of the depth and nuances of the problems facing children at risk in the twenty-first century. And reading about the work that has been done already, we are inspired with hope for solutions through greater understanding of the challenges and with the continued dedication of concerned people and organizations that are engaged throughout the world in protecting the most vulnerable and precious of human resources.

\section{Notes}

1. "Death of 27,000 children barely noticed," The Toronto Star, 1 October 1 2001; "Worldwide abuse of children 'global scandal,' group says," The Toronto Star, 28 September 2001.

2. The United Nations Convention on the Rights of the Child, adopted by the United Nations in November 1989, has been ratified by 191 countries; only the United States (which has signed the Convention indicating its intention to ratify it) and Somalia (which has had no recognized government since 1991) have not ratified the UNCRC. See Convention on the Rights of the Child <http://www. unicef.org/crc/convention.htm>.

Geraldine Sadoway received her LL.B. from Osgoode Hall Law School in 1981 and was called to the Ontario Bar in 1983. From 1983 until 1997 she was a lawyer in private practice in Toronto, specializing in immigration and refugee law. From 1995 to 2000 she taught the immigration law course for Queen's University Faculty of Law. Since 1997 she has been the staff lawyer for the immigration law group at Parkdale Community Legal Services in Toronto, supervising law students in the Osgoode clinical law program at PCLS. 